\title{
Effect of different types of mulch on bulb yield of shallot
}

\author{
Gina Aliya Sopha*, and Agnofi Merdeka Efendi \\ Indonesian Vegetable Research Institute, Jl Tangkuban Perahu 517 Lembang no 517 Lembang
}

\begin{abstract}
The possibility of using different types of mulch to improve the bulb yield of shallot (Allium cepa var aggregatum) is observed in this paper. The field experiment compared five different types of mulches, including silver, black, straw, screen nylon, and clear plastic mulches, with a nonmulch as a control treatment. Straw mulch and screen nylon mulch reduced shallot biomass but did not significantly affect bulb yield than the control treatment. At the same time, clear plastic mulch increased fresh bulb yield significantly by $30 \%$ from $10.26 \mathrm{tha}^{-1}$ to $13.29 \mathrm{tha}^{-1}$.
\end{abstract}

\section{Introduction}

Shallot (Allium cepa var aggregatum) is one of Indonesia's most important vegetable crops, and it was used in many traditional Indonesian cuisines. The largest shallot production area is Central Java. In 2018, the harvested area in Central Java was 46316 ha, the total production was $445583 \mathrm{t}$, and the fresh bulb yield was about $9.62 \mathrm{t} \mathrm{ha}^{-1}$ [1]. However, the average bulb yield was lower than the potential bulb yield that can be achieved in this region. For example, the potential bulb yield of shallot cultivar 'Kuning' was $26 \mathrm{t} \mathrm{ha}^{-1}$ [2] and the bulb yield of 'Bima' and 'Bangkok' up to 21 to $23 \mathrm{t}$ ha, respectively when the number of populations was 300.000 plants/ha [3].

The gap differences between the potential yield and on-farm bulb yield create room for improvement, especially the agronomic aspect that might significantly interfere with the shallot bulb yield. One of the critical factors that highly contribute to the shallot bulb yield is soil moisture. Water availability is essential for plants. It is necessary for nutrient uptake and plant growth. Drought stress reduces the length and leaf area of onion [4], decreasing the bulb yield. One of the biggest of water loss is evapotranspiration that can be minimized by soil mulching.

Soil mulching could reduce soil evaporation by $45 \%$, the total evapotranspiration by $5 \%$ and increased water use efficiency up to $13 \%$ [5]. However, the effect of mulch varies on mulch type and region. For example, straw mulch decreases temperature and evapotranspiration on the soil surface, leading to increased crop yield in the temperate region but reduced crop yield in semiarid areas because of lower soil surface temperature [6-8]. In contrast, the application of plastic film mulching was reported to positively impact increasing crop yield in many species such as spring wheat [9], corn, cotton, and many vegetables and fruits [10-12]. Furthermore, there were some mulch types available in the market that might

\footnotetext{
* Correspondent author: ginasopha80@gmail.com
} 
be used for shallot. Therefore, this research investigated the effect of various mulch types on the growth and bulb yield of shallot in Central Java, Indonesia.

\section{Materials and method}

\subsection{Time and location}

The experiment was carried out at the farmer's farms in Brebes, Kabupaten Brebes, Central Java, Indonesia ( $4 \mathrm{~m}$ above sea level). The total rainfall during the experiment from March to May 2016 was $239.3 \mathrm{~mm}$ with monthly average air temperature was $28.8^{\circ} \mathrm{C}$, the monthly minimum temperature was $26.2^{\circ} \mathrm{C}$, and the monthly maximum temperature was $32.6^{\circ} \mathrm{C}$. The soil is clay soil, alluvial soil with initial soil $\mathrm{pH}$ of 5.9

\subsection{Treatments}

Shallot cultivar 'Bima Brebes' was planted on the bed with row spacing $15 \times 20 \mathrm{~cm}$ or about 300.000 plants/ha (land efficiency about $70 \%$ ). Space was $50 \mathrm{~cm}$ wide between beds, with a height of about $80 \mathrm{~cm}$. The furrow irrigation was applied with the height of water about 40 $\mathrm{cm}$. A Compound fertilizer NPK (15:15:15) rate $1 \mathrm{t} \mathrm{ha}^{-1}$ was applied twice before and three weeks after planting, each at a half rate. About $15 \mathrm{tha}^{-1}$ of goat manure was also applied as a base fertilizer incorporated with NPK fertilizer three days before planting. Pesticides and fungicides-controlled pest and disease incidence. About $2 \mathrm{~g} \mathrm{l}^{-1}$ of fungicide Daconil $75 \mathrm{WP}$ was sprayed every week, and $2 \mathrm{ml} \mathrm{l}^{-1}$ of insecticide Decis $2.5 \mathrm{EC}$, Cascade $50 \mathrm{EC}$ and Hostathion 40 EC was applied every week alternately.

The experiment comprised various mulch types: silver, black, straw, screen nylon, and clear plastic mulches, with no mulch as a control treatment. The Individual plots are $10 \mathrm{~m}$ long and $1.5 \mathrm{~m}$ wide, with four replications using randomized complete block design with a total population of about 350 plants per plot.

Beds were raised and flatted. Before planting time, mulches were laid flat on the soil surface, and the edges closed tightly with the soil. By using a hot can, planting holes were made with the desired plant spacing. For every planting hole, one or two shallot bulb seeds were planted. Treatment effects were analyzed using F-test with the SAS program.

\section{Results and discussion}

In overview, the plants grew well up to 5 weeks after planting. However, at six weeks after planting, there were severe incidences of Peronospora destructor (dew mildew), Alternaria porii (purple spot) and Colletotrichum sp (anthracnose) due to heavy rainfall and high relative humidity (Table 1). On plant leaf surface appeared white spots, the expanded to brown or purplish spots. The severe symptom led to yellowing the leaves and eventually died. As a result, many plants are rotten or dead, including the mulch treatments.

Table 1. The weather data at Brebes during the experiment

\begin{tabular}{|l|c|c|c|c|}
\hline \multirow{2}{*}{ Month } & \multicolumn{2}{|c|}{ Temperature $\left({ }^{\circ} \mathrm{C}\right)$} & $\begin{array}{c}\text { Relative } \\
\text { humidity (\%) }\end{array}$ & Rainfall (mm) \\
\cline { 2 - 3 } & Maximum & Minimum & 90,07 & 274,5 \\
\hline May & 24,87 & 14,90 & 87,93 & 310,5 \\
June & 25,25 & 14,64 & 88,40 & 335,0 \\
July & 24,42 & 14,35 & \\
\hline
\end{tabular}


Shallot 'Bima Brebes' commonly start to bulb at 35 days after planting and reach the optimal vegetative growth at the same time. After that, the bulbs will be getting bigger, and the leaves will collapse. The harvesting time occurs when all the leaves are falling over, about 60 days after planting.

It was found that there was no significant difference between treatments on plant height at 35 days after plating, but the application of mulch affected the number of leaves and tillers per plant (Table 2). The number of leaves in screen nylon and the Control was significantly lower than clear plastic mulch treatment. In comparison, the other mulch treatments were not significantly different in the number of leaves. The high incidence of diseases in the screen nylon and the Control treatments might interfere with the number of leaves in those treatments. The Control treatment gained the lowest number of leaves, about 35 leaves, that was 12 leaves is lesser than clear plastic mulch, 47 leaves.

Similar to [13], there was no effect on the shallot height of black plastic and straw mulch. However, applying any type of mulches except black plastic mulch increased the number of tillers compared to control. Silver plastic mulch produced the highest tiller numbers, clear plastic, screen nylon, straw, black plastic, and Control. The straw mulch application has a positive effect on shallot growth also reported by [14] that the application of straw mulch increased the number of shallot leaves.

Table 2. Effect of different types of mulches on shallot growth and bulb yield

\begin{tabular}{|l|c|c|c|}
\hline \multicolumn{1}{|c|}{ Treatments } & $\begin{array}{c}\text { Number of } \\
\text { leaves }\end{array}$ & Plant height (cm) & Number of tillers \\
\hline Silver plastic mulch & $42.13 \mathrm{a}$ & $44.16^{\mathrm{ns}}$ & $8.97 \mathrm{a}$ \\
Black plastic mulch & $38.15 \mathrm{ab}$ & 43.02 & $6.91 \mathrm{bc}$ \\
Straw mulch & $39.53 \mathrm{ab}$ & 14.18 & $7.274 \mathrm{~b}$ \\
Screen nylon mulch & $37.60 \mathrm{~b}$ & 40.94 & $8.04 \mathrm{ab}$ \\
Clear plastic mulch & $46.60 \mathrm{a}$ & 43.29 & $8.36 \mathrm{ab}$ \\
No-mulch (Control) & $35.48 \mathrm{~b}$ & 40.67 & $6.61 \mathrm{c}$ \\
\hline CV (\%) & 11.9 & 7.7 & 11.4 \\
\hline
\end{tabular}

Means within columns followed by different letters are significantly different at $P=0.05$; ns $=$ no significance difference.

The plant grew well until the harvest time, and the plant stand for each treatment can be seen in Fig. 1. The plants were grown well, and there was no severe incidence of pests and diseases. 


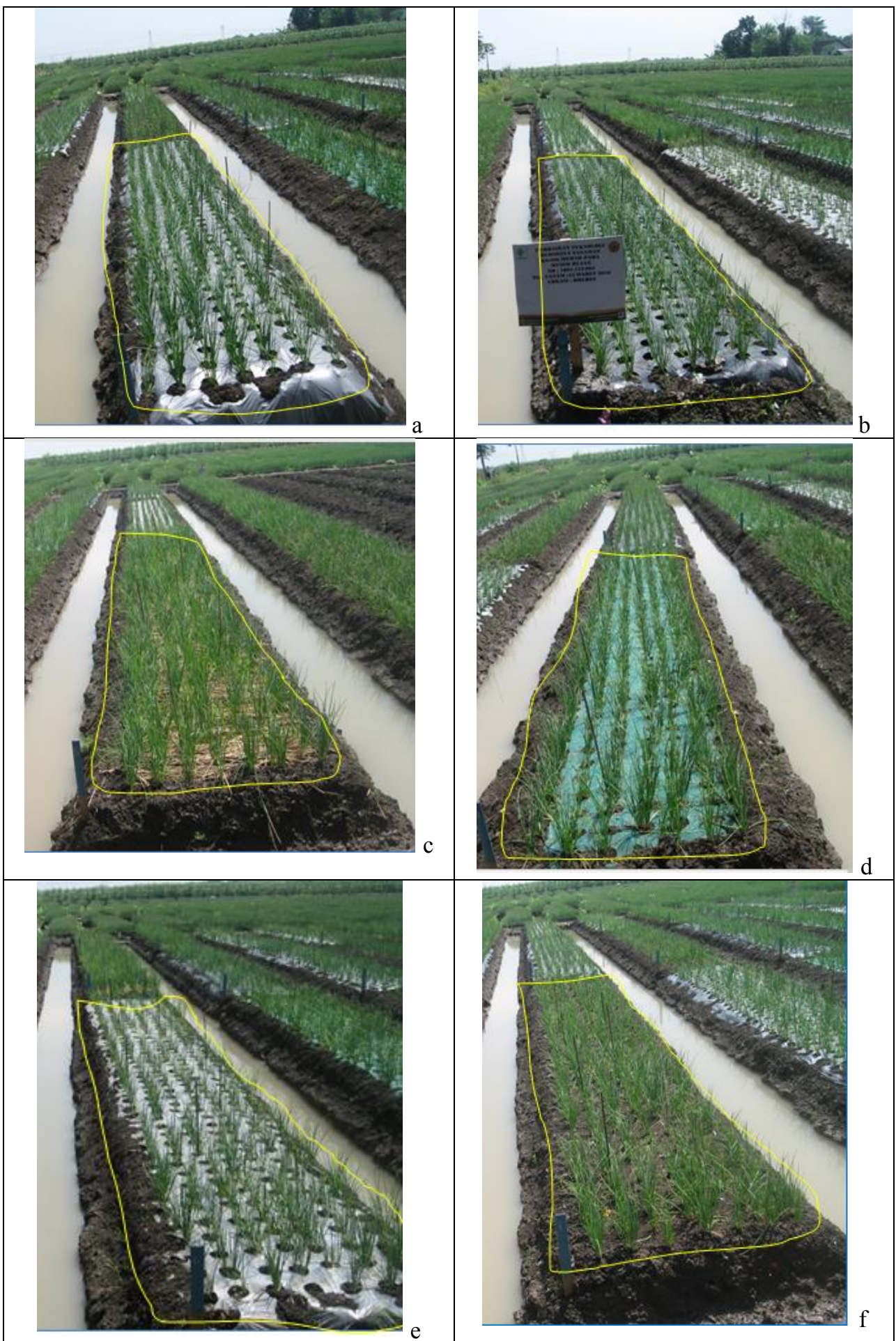

Fig 1. Plant performance at 25 days after planting in (a) plastic silver mulch, (b) black plastic mulch, (c) straw mulch, (d) screen nylon mulch, (e) clear plastic mulch, (f) no-mulch (Control). 
Mulches had a different effect on shallot biomass (Table 4). Clear plastic mulch achieved the highest plant biomass, $19.16 \mathrm{t} \mathrm{ha}^{-1}$, about $12 \%$ higher than the Control. On the contrary, the application of screen nylon mulch reduced the plant biomass by about $17 \%$ than the Control.

Table 4. The effect of mulch on shallot biomass $\left(\mathrm{t} \mathrm{ha}^{-1}\right)$ and bulb yield $\left(\mathrm{t} \mathrm{ha}^{-1}\right)$

\begin{tabular}{|l|c|c|}
\hline \multicolumn{1}{|c|}{ Treatments } & Plant biomass $\left(\mathbf{t ~ h a}^{-\mathbf{1}}\right)$ & \left.${\text { Bulb Yield }\left(\mathbf{t ~ h a}^{-1}\right)}^{\mathbf{1}}\right)$ \\
\hline Silver plastic mulch & $18.21 \mathrm{ab}$ & $12.23 \mathrm{ab}$ \\
Black plastic mulch & $17.29 \mathrm{ab}$ & $11.22 \mathrm{~b}$ \\
Straw mulch & $16.34 \mathrm{~b}$ & $12.01 \mathrm{~b}$ \\
Screen nylon mulch & $14.12 \mathrm{c}$ & $11.28 \mathrm{~b}$ \\
Clear plastic mulch & $19.16 \mathrm{a}$ & $13.29 \mathrm{a}$ \\
No-mulch (Control) & $17.11 \mathrm{ab}$ & $10.26 \mathrm{~b}$ \\
\hline CV (\%) & 14.3 & 12.5 \\
\hline
\end{tabular}

Means within columns followed by different letters are significantly different at $P=0.05$; ns $=$ no significance difference.

In overview, all treatments had a good bulb yield. On average, the bulb yield was above $10 \mathrm{t} \mathrm{ha}^{-1}$ higher than the average farmer's bulb yield in this region. However, the bulb yield was still lower than the potential yield, about $21 \mathrm{t} \mathrm{ha}^{-1}$ that can be achieved in the favourable environment. The clear plastic mulch also increased shallot bulb yield significantly than Control, but not other mulch treatments. The application of silver plastic, black plastic, straw mulches, and screen nylon mulch did not significantly affect shallot bulb yield.

In comparison, the application of clear plastic mulch improved the bulb yield by $30 \%$ than Control. The high yield in clear plastic mulch occurred due to the high biomass in this treatment. Plant biomass has a positive relationship with bulb yield [15].

The different responses of bulb yield on the different mulch types were also reported by [16]. Mulching might promote root development and increase water and nutrient uptake [17, 18], increasing the below-ground section of biomass (roots and bulbs). Therefore, it results in high bulb yield components. The application of clear plastic mulch increased shallot bulb yields significantly by $30 \%$ than that of the Control. The same response was reported by [4] that the application of clear plastic mulch enhanced spring wheat yields due to increasing photosynthetic and transpiration accumulation and improved water use efficiency.

The different effects of mulch types on shallot growth and bulb yield might be due to the differences in mulch materials. Despite reduced evapotranspiration, mulches also reduce the weed population, limiting the competition between weeds and plants. Film colour from plastic mulches affected weed seed germination, interfering with the competition between weed and plants [19]. The clear plastic mulch might interfere with the weed germination, reducing the weed population and increasing the shallot biomass, leading to a high yield.

Straw and screen nylon mulches had a higher harvest index than the Control (Table 5). The harvest index was measured by divided the bulb yield with the plant biomass. This finding shows how efficient a photosynthate distributes to the plant's economically part, in this term, the bulb. Many factors, especially temperature, influence bulb development. Leaf and bulb development linearly increased temperature from 7 to $27^{\circ} \mathrm{C}$, while mulch application increases soil temperature. Clear plastic mulch increased soil temperature up to $3^{\circ} \mathrm{C}$, black plastic mulch increased about $1.5^{\circ} \mathrm{C}$, and straw mulch increased the temperature by $2^{\circ} \mathrm{C}[20]$. Thus, it seems that mulch improves shallot bulb development by increasing the photosynthate translocation to the bulb as the effect of soil temperature alteration. 
Table 5. The effect of mulch on harvest index

\begin{tabular}{|l|c|}
\hline Treatments & Harvest Index \\
\hline Silver plastic mulch & $0.67 \mathrm{ab}$ \\
Black plastic mulch & $0.65 \mathrm{ab}$ \\
Straw mulch & $0.74 \mathrm{a}$ \\
Screen nylon mulch & $0.80 \mathrm{a}$ \\
Clear plastic mulch & $0.69 \mathrm{ab}$ \\
No-mulch (Control) & $0.60 \mathrm{~b}$ \\
\hline CV (\%) & 13.4 \\
\hline
\end{tabular}

There was no effect of mulches on bulb quality, bulb diameter and weight loss (Table 6). The bulb diameter was in the range of 2.21 to $2.51 \mathrm{~cm}$. At the same time, the weight loss for seven days is about 35 to $45 \%$ from the fresh bulb yield. The application of black plastic mulch gave the highest percentage of weight loss. In comparison, the application of straw mulch reduced the percentage of weight loss. Control also has a high percentage of weight loss, after seven days, about $41 \%$. Therefore, the application of clear plastic mulch reduced the weight loss by $3 \%$ than the Control.

Table 6. The effect of mulch treatment on bulb diameter (cm) and weight loss (\%)

\begin{tabular}{|l|c|c|}
\hline Treatments & Bulb diameter $(\mathrm{cm})$ & $\begin{array}{c}\text { Weight loss after seven days } \\
(\%)\end{array}$ \\
\hline Silver plastic mulch & $2.51^{\mathrm{ns}}$ & $37.29^{\mathrm{ns}}$ \\
Black plastic mulch & 2.34 & 45.10 \\
Straw mulch & 2.21 & 35.74 \\
Screen nylon mulch & 2.32 & 41.75 \\
Clear plastic mulch & 2.26 & 38.53 \\
No-mulch (Control) & 2.32 & 41.47 \\
\hline CV (\%) & 10.13 & 13.13 \\
\hline
\end{tabular}

\section{Conclusion}

Clear plastic mulch increased plant biomass and fresh bulb yield significantly by 12 and $30 \%$, respectively, from the Control. The Control bulb yield was $10.26 \mathrm{t} \mathrm{ha}^{-1}$ that increased to 13.29 $\mathrm{t} \mathrm{ha}^{-1}$. Application clear plastic mulch also reduced the weight loss of bulb yield.

Acknowledgement. The authors said thanks to Ir. Subhan to supervise the fieldwork and manuscript.

\section{References}

1. BPS, Statistik Tanaman sayuran dan Buah-buahan Semusim, BPS-Statistic Indonesia (2018)

2. Yulianto, J. Agroland, 15, 3: p. 148-155 (2008)

3. Sopha, G.A., R. Rosliani, R.S. Basuki, L. Liferdi, and M. P. Yufdy. AAB Bioflux, 7, 2:p. 127-137 (2015)

4. Ghodke, P.J., P.S. Andhale, U.M. Gijare. A. Thangasamy, Y.P Khade, V. Mahajan, and M. Singh. Int. J. Curr. Microbiol. App. Sci. 7, 1:p. 2054-2062 (2018)

5. Zhang, Y., J. Wang, S. Gong, D. Xu, J. Sui, Z. Wu, and Y. Mo. Agricultural Water Management, 205:p. 90-99 (2018)

6. Langdale, G., Soil Technology, 5,1: p. 81-90 (1992) 
7. Cantero-Martinez, C., G. O'Leary, and D. Connor, Soil and Tillage Research, 34, 2: p. 79-94 (1995)

8. Gao, S. and S. Zhao, Acta Botan Boreali-Occidental Sin, 1995. 15, 8: p. 32-39 (1995)

9. Li, F.-M., A.-H. Guo, and H. Wei, Field Crops Research, 63, 1: p. 79-86 (1999)

10. Luo, J., Gansu Agric Sci Tech, 2: p. 6-9 (1992)

11. Zhang, S. and T. Ma, Gansu Agric. Sci. Tech.1: p. 16-17 (1994)

12. Han, Y. and X. Wan, Gansu Agric Sci Tech, 1995. 8: p. 14-16 (1995)

13. Novayana, D., R. Sipayung, and A. Barus, Jurnal Agroekoteknologi Universitas Sumatera Utara, 3, 2: p. 103720 (2015)

14. Mayun, I.A., Agritrop, 26(1): p. 33-40 (2007)

15. Abdissa, Y., T. Tekalign, and L.M. Pant. African Journal of Agricultural Research, 6, 14:p. 3252-3258 (2011)

16. Lasmini, S.A. and I. Wahyudi, Jurnal Hortikultura Indonesia, 9, 2: p. 103-110 (2018)

17. Boatwright, G., H. Ferguson, and J. Sims, Agronomy Journal, 68, 2: p. 227-231 (1976)

18. Cumbus, I. and P. Nye, Emerald. Journal of experimental botany, 36, 2: p. 219-227 (1985)

19. Nguoajio, M., J. Ernest. Hortscience, 39, 6: p. 1302-1304 (2004)

20. Woldestadik, K. Hortscience. 38, 2: p.217-221 (2003) 